\title{
KECEMASAN PRIMIPARA DALAM MENGHADAPI PERSALINAN DI KLINIK BERSALIN N. TAMBUNAN MEDAN
}

\author{
NURHAMIDA FITHRI \\ STIKes SENIOR MEDAN \\ JL. Jamin Ginting KM.8,5 No.13, Mangga, Kec. Medan Tuntungan, \\ Kota Medan, Sumatera Utara \\ e-mail :pitipitinez@gmail.com
}

DOI $10.35451 / j k k . v 3 i 2.602$

\begin{abstract}
Feelings of anxiety often accompany pregnancy, especially in mothers who are unstable, from an initial survey conducted by researchers in February at the $N$. Tambunan Clinic, it was found that five mothers who had given birth at the $N$. Tambunan Clinic felt anxious, the purpose of this study was to determine how the primiparous mother's anxiety in dealing with childbirth. Primiparous mother's anxiety in facing childbirth is the occurrence of disequilibirium or imbalance in personality characterized by physical and psychological changes. The research design used is descriptive. The population of this study were all Primipara women totaling 30 people at the Clinic N. Tambunan Medan. With a sample of 30 respondents. The sampling technique was purposive sampling technique. The variable in this study was the primiparous mother's anxiety in dealing with childbirth. Collecting data using a questionnaire then processed by editing, coding, data entry, the research is presented and analyzed by univariate, then the data is presented in the form of a frequency distribution table. Of the 30 respondents, there were 27 patients who experienced mild anxiety, 3 patients experienced moderate anxiety, and none had severe anxiety. The conclusion from the results of the study was that most mothers experienced mild anxiety. Therefore, it is hoped that midwives will provide more intensive counseling to pregnant women who experience anxiety by providing information about the danger signs of pregnancy and suggesting always thinking positively, sharing stories with others, thinking about something that makes you happy to avoid anxiety.
\end{abstract}

Keywords: Anxiety, Mother Primipara, Childbirth

\section{Pendahuluan}

Kehamilan anak pertama, merupakan tahap dimana terjadi disequilibrium atau ketidakseimbangan dalam kepribadian seoarang wanita. Karena pada masa tersebut, seorang perempuan mulai dihadapkan pada tugas, dan peran baru sebagai seorang ibu.

Kehamilan pertama kali bagi seorang calon ibu, merupakan satu perjalanan baru, yang ditandai dengan perubahan-perubahan fisik dan psikis sehingga timbul berbagai masalah psikologi. Peristiwa yang belum pernah dialami sebelumnya akan menimbulkan rasa cemas, takut, gelisah, tegang bercampur was-was. Reaksi fisik yang mungkin muncul dari rasa cemas dapat berupa ujung jari terasa dingin, jantung berdebar-debar lebih cepat, nafsu 
makan berkurang, kepala pusing dan sesak nafas.

Dinamika psikologi yang dialami ibu hamil anak pertama yaitu perasaan bahagia, cemas, mudah menangis, mudah tersinggung, sering bermimpi, berkhayal dan memikirkan hal yang bukan-bukan. Ibu yang mengandung calon anak pertama bias saja mengalami beragam perasaan cemas pada waktu yang bersamaan saat mengetahui berat badan bayi terlalu kecil, tekanan darah rendah, adanya perdarahan, kemungkinan abortus atau bayi lahir premature. Ibu yang demikian biasanya selalu memebayangkan persalinan dan mendengar cerita tentang yang bermasalah. Perasaan cemas sering kali menyertai kehamilan terutama pada seoarang ibu yang berjiwa labil. Kecemasan ini mencapai puncaknya pada saat persalinan. Rasa nyeri pada waktu persalinan sudah sejak dulu menjadi pembicaraan mengenai kehamilan dan persalinan (Detiana, 2014).

Rasa cemas dapat timbul akibat khawatir akan nyeri persalinan, mutilasi dan khawatir terhadap proses persalinan yang tidak berjalan lancar atau tidak terjadinya persalinan yang aman bagi dirinya dan janinnya. Kecemasan merupakan salah faktor penyebab AKI karena cemas dapat mempengaruhi turun naiknya kadar hormone. (Maryuni, 2013)

Masalah kehamilan dan persalinan merupakan fokus perhatian yang sangat penting dalam kehidupan masyarakat pada proses persalinan. Kecemasan menjelang persalinan umum dialami oleh ibu. Meskipun persalinan adalah suatu hal yang fisiologis, namun didalam menghadapi proses persalinan dimana terjadi serangkaian perubahan fisik dan psikologis yang dimulai dari terjadinya kontraksi rahim, dilatasi jalan lahir, dan pengeluaran bayi serta plasenta yang diakhiri dengan awal anatara ibu dan bayi (Rooije R, 2015).

Persalinan sebagai masa yang cukup berat bagi seorang ibu dapat menimbulkan perasaan cemas. Kecemasan biasanya akan lebih besar dirasakan oleh ibu yang pertama kali hamil atau primigravida karena hanya mengetahui sedikit perubahanperubahan yang terjadi pada dirinya dan mereka belum memilki pengalaman melahirkan, sehingga kecemasan membuat kehamilan mereka kurang menyenangkan. Peristiwa yang belum pernah dialami sebelumnya akan menimbulakan rasa cemas, takut, gelisah, tegang bercampur was-was. Reaksi fisik yang mungkin muncul dari rasa cemas dapat berupa ujung jari terasa dingin, jantung berdebar-debar lebih cepat, nafsu makan berkurang, kepala pusing dan sesak nafas (Risky A, 2010)

Berdasarkan penelitian mahasiswa Universitas Sumatera Utara tentang faktor-faktor yang mempengaruhi kecemasan pada ibu bersalin primigravida kala 1 di RSU. Pirngadi Medan yang merupakan Rumah Sakit pemerintah dengan kunjungan persalinan lebih kurang 1.371 pertahun, dengan rata-rata 110 orang yang bersalin perbulannya,bahwasanya dari hasil wawancara dengan petugas di ruang bersalin yang merawat langsung ibu-ibu yang melahirkan diruang perawatan diketahui bahwa ibu saat persalinan pertama khususnya pada kala I sering mengalami kecemasan yang ditandai dengan tegang, bingung, sering bertanya kepada petugas tentang perkembangan kemajuan persalinan, perasaan tidak menentu, gelisah dan gampang menangis.

Dari survey awal yang dilakukan peneliti pada September di Klinik N.Tambunan Medan, di temukan dari lima ibu yang pernah bersalin di klinik tersebut menyatakan merasa cemas 
pada saat menghadapi persalinan pertamanya dikarenakan ibu tersebut baru pertama sekali hamil dan baru pertama sekali menghadapi persalinan, mereka merasa cemas, takut dan tegang akan keadaan yang akan dialami mereka dan mereka takut akan sakit dan nyeri yang di akibatkan oleh persalinan tersebut.

\section{METODE}

Desain penelitian yang digunakan dalam penelitian ini bersifat penelitian deskriptif dengan pendekatan cross sectional. Sampel pada penelitian ini adalah ibu primipara yang melahirkan di Klinik N. Tambunan dengan jumlah 30 orang ibu primipara. Waktu penelitian ini berlangsung 8 minggu dari bulan Oktober s/d Desember 2020 Penelitian ini menggunakan instrument kuesioner sebagai alat ukur dengan bentuk pernyataan tertutup (closes ended). Aspek pengukuran pada instrument kuesioner dihitung dalam bentuk skala Likert. Instrumen pada penelitian ini berupa kuesioner yang dibuat oleh peneliti berdasarkan tinjauan teoritis. Analisis yang digunakan adalah univariat untuk mengetahui distribusi frekuensi karakteristik ibu primipara dan bentuk kecemasan.

\section{HASIL}

Pada penelitian ini mencakup gambaran kecemasan responden dalam menghadapai persalinan dilihat dari segi usia, pendidikan, pekerjaan, lama menikah suku, dan penghasilan perbulan. Secara rinci dapat dilihat sebagai berikut :

Tabel 1.Distribusi Frekuensi Karakteristik Responden yang mengalami kecemasan dalam Menghadapi Persalinan Di Klinik N. Tambunan Medan Tahun 2020

\begin{tabular}{|c|c|c|}
\hline Karakteristik & $\mathbf{n}$ & $\%$ \\
\hline \multicolumn{3}{|l|}{ Usia } \\
\hline 18-22 tahun & 12 & 40,0 \\
\hline 23-27 tahun & 13 & 43,3 \\
\hline 28-32 tahun & 5 & 16,6 \\
\hline Total & 30 & $100 \%$ \\
\hline \multicolumn{3}{|l|}{ Pendidikan } \\
\hline SLTA & 1 & 3,3 \\
\hline SMP & 2 & 6,6 \\
\hline SMA & 18 & 60,0 \\
\hline SMK & 5 & 16,6 \\
\hline Perguruan & 4 & 13,3 \\
\hline Tinggi & & \\
\hline Total & 30 & $100 \%$ \\
\hline \multicolumn{3}{|l|}{ Pekerjaan } \\
\hline IRT & 26 & 86,6 \\
\hline Wiraswasta & 1 & 3,3 \\
\hline Pegawai Swasta & 1 & 3,3 \\
\hline Pegawai BUMD & 1 & 3,3 \\
\hline Guru & 1 & 3,3 \\
\hline Total & 30 & $100 \%$ \\
\hline \multicolumn{3}{|l|}{ Lama Menikah } \\
\hline 1-2 tahun & 20 & 66,6 \\
\hline 3-4 tahun & 10 & 33,3 \\
\hline Total & 30 & $100 \%$ \\
\hline \multicolumn{3}{|l|}{ Suku } \\
\hline Jawa & 13 & 43,3 \\
\hline Batak & 7 & 23,3 \\
\hline Padang & 2 & 6,6 \\
\hline Mandailing & 6 & 20,0 \\
\hline Aceh & 2 & 6,6 \\
\hline Total & 30 & $100 \%$ \\
\hline \multicolumn{3}{|l|}{$\begin{array}{l}\text { Penghasilan } \\
\text { Perbulan }\end{array}$} \\
\hline <Rp.1.000.000, & 9 & 30 \\
\hline $\begin{array}{l}\text {-Rp.1.000.000 } \\
\text { s/d 2.000.000,- }\end{array}$ & 18 & 60 \\
\hline $\begin{array}{l}>\text { Rp. } 2.000 .000, \\
-\end{array}$ & 3 & 10 \\
\hline Total & 30 & $100 \%$ \\
\hline
\end{tabular}

Dari tabel 1 menunjukkan bahwa berdasarkan umur 13 orang responden $(43,33 \%)$ berusia $23-27$ tahun, berdasarkan tingkat pendidikan responden yang berpendidikan SMU adalah 18 orang $(60 \%)$, berdasarkan pekerjaan responden yang hanya bekerja sebagai ibu rumah tangga adalah 26 orang $(86,66 \%)$, berdasarkan lama menikah adalah 20 orang $(66,66 \%)$, 
berdasarkan suku adalah 13 orang $(43,33 \%)$, dan berdasarkan penghasilan perbulan responden yang berpengasilan kurang dari Rp.1.000.000-2.000.000,- adalah 18 orang $(60 \%)$.
Tabel 2.Distribusi Frekuensi Kecemasan Ibu Primipara dalam Menghadapi Persalinan Di Klinik N. Tambunan Medan Tahun 2020

\begin{tabular}{|c|c|c|c|c|c|c|c|c|}
\hline \multirow[t]{2}{*}{ Penyataan } & \multicolumn{2}{|c|}{$\begin{array}{l}\text { Tidak sama } \\
\text { sekali }\end{array}$} & \multicolumn{2}{|c|}{$\begin{array}{l}\text { Iya, tapi tidak } \\
\text { begitu } \\
\text { mengganggu }\end{array}$} & \multicolumn{2}{|c|}{$\begin{array}{c}\text { Kadang- } \\
\text { kadang, tapi } \\
\text { tidak } \\
\text { menyenangk } \\
\text { an }\end{array}$} & \multicolumn{2}{|c|}{$\begin{array}{c}\text { sangat } \\
\text { menggangg } \\
\mathrm{u}\end{array}$} \\
\hline & $\mathbf{n}$ & $\%$ & $\mathbf{n}$ & $\%$ & $\mathbf{n}$ & $\%$ & $\mathbf{n}$ & $\%$ \\
\hline \multicolumn{9}{|c|}{ Kecemasan } \\
\hline $\begin{array}{l}\text { Ibu merasa khawatir akan terjadi sesuatu yang } \\
\text { buruk pada saat menghadapi persalinan }\end{array}$ & 2 & 6,6 & 25 & 83,3 & 3 & 10 & - & - \\
\hline Ibu takut akan kematian pada saat persalinan & 5 & 16,6 & 12 & 40 & 7 & 23,3 & 6 & 20 \\
\hline $\begin{array}{l}\text { Ibu merasa sulit berkonsentrasi pada saat } \\
\text { menghadapi persalinan }\end{array}$ & 9 & 30 & 19 & 63,3 & 2 & 6,6 & - & - \\
\hline $\begin{array}{l}\text { Ibu merasa emosi meningkat pada saat } \\
\text { menghadapi persalinan }\end{array}$ & 14 & 46,6 & 14 & 46,6 & 2 & 6,6 & - & - \\
\hline $\begin{array}{l}\text { Ibu merasa takut pada saat menghadapi } \\
\text { persalinan }\end{array}$ & 8 & 26,6 & 20 & 66,6 & 2 & 6,6 & - & - \\
\hline Ibu bingung pada saat menghadapi persalinan & 15 & 50 & 15 & 50 & - & - & - & - \\
\hline \multicolumn{9}{|c|}{ Ketegangan Motorik } \\
\hline $\begin{array}{l}\text { Ibu merasa tegang pada otot-otot leher, dada dan } \\
\text { punggung }\end{array}$ & 14 & 46,6 & 15 & 50 & 1 & 3,3 & - & - \\
\hline $\begin{array}{l}\text { Ibu gelisah dan melakukan banyak gerak seperti } \\
\text { berjalan-jalan atau mondar mandir }\end{array}$ & 4 & 13,3 & 18 & 60 & 8 & 26,6 & - & - \\
\hline $\begin{array}{l}\text { Ibu menggoyangkan tungkai kaki pada saat } \\
\text { menghadapi persalinan }\end{array}$ & 13 & 43,3 & 15 & 50 & 2 & 6,6 & - & - \\
\hline $\begin{array}{l}\text { Ibu merasa gemetar pada saat menghadapi } \\
\text { persalinan }\end{array}$ & 3 & 10 & 19 & 63,3 & 8 & 26,6 & - & - \\
\hline Ibu merasa tidak tenang menghadapi persalinan & 10 & 33,3 & 17 & 56,6 & 2 & 6,6 & 1 & 3,3 \\
\hline $\begin{array}{l}\text { Ibu menggenggam sesuatu dengan erat pada saat } \\
\text { menghadapi persalinan }\end{array}$ & 5 & 16,6 & 19 & 63,3 & 6 & 20 & - & - \\
\hline $\begin{array}{l}\text { Ibu memukuli orang lain dan diri sendiri pada saat } \\
\text { menghadapi persalinan }\end{array}$ & 22 & 73,3 & 8 & 26,6 & - & - & - & - \\
\hline \multicolumn{9}{|c|}{ Overaktifitas Otonomik } \\
\hline $\begin{array}{l}\text { Ibu merasa kehilangan kesadaran pada saat } \\
\text { menghadapi persalinan }\end{array}$ & 14 & 46,6 & 15 & 50 & - & - & 1 & 3,3 \\
\hline $\begin{array}{l}\text { Ibu banyak mengeluarkan keringat yang cukup } \\
\text { banyak pada saat menghadapi persalinan }\end{array}$ & 2 & 6,6 & 27 & 90 & 1 & 3,3 & - & - \\
\hline $\begin{array}{l}\text { Ibu merasa jantungnya berdebar-debar pada saat } \\
\text { menghadapi persalinan }\end{array}$ & 3 & 10 & 21 & 70 & 6 & 20 & - & - \\
\hline $\begin{array}{l}\text { Ibu merasa sesak nafas ketika menghadapi } \\
\text { persalinan }\end{array}$ & 20 & 66,6 & 10 & 33,3 & - & - & - & - \\
\hline $\begin{array}{l}\text { Ibu mengalami gangguan pencernaan pada saat } \\
\text { menghadapi persalinan }\end{array}$ & 20 & 66,6 & 8 & 26,6 & 1 & 3,3 & 1 & 3,3 \\
\hline $\begin{array}{l}\text { Mulut ibu terasa kering pada saat menghadapi } \\
\text { persalinan }\end{array}$ & 9 & 30 & 21 & 70 & - & - & - & - \\
\hline $\begin{array}{l}\text { Ibu merasakan panas khususnya pada bagian } \\
\text { belakang kepala pada seluruh tubuh pada saat } \\
\text { menghadpi persalinan }\end{array}$ & 8 & 26,6 & 20 & 66,6 & 2 & 6,6 & - & - \\
\hline Total Rata-Rata & 10 & 33,2 & 16,9 & 56,3 & 2.65 & 10,7 & 0,45 & $\mathbf{1}, \mathbf{5}$ \\
\hline
\end{tabular}

Dari tabel 2 dapat dilihat pada tanda gejala kecemasan yaitu 2 orang responden $(6,6 \%)$ menyatakan tidak sama sekali khawatir akan terjadi sesuatu yang buruk pada saat menghadapi persalinan, 25 orang responden $(83,3 \%)$ menyatakan iya,tapi tidak begitu mengganggu menyatakan khawatir akan terjadi sesutau yang buruk pada saat menghadapi persalinan, 3 orang 
responden (10\%) menyatakan kadang-kadang, tapi tidak menyenangkan.

Pada tanda gejala ketegangan motorik yaitu 14 orang responden $(46,6 \%)$ menyatakan tidak sama sekali merasa tegang pada otot-otot leher, dada dan punggung, 15 orang responden (50\%) menyatakan iya, tapi tidak mengganggu menggoyangkan tungkai kaki pada saat menghadapi persalinan, 1 orang responden $(3,3 \%)$ menyatakan kadang-kadang, tapi tidak menyenangkan merasa tegang pada otot-otot leher, dada dan punggung.

Pada tanda gejala overaktifitas otonomik 14 orang responden $(46,6 \%)$ menyatakan tidak sama sekali merasa kehilangan kesadaran pada saat menghadapi persalinan, 15 orang reponden (50\%) menyatakan iya, tapi tidak mengganggu merasa kehilangan kesadaran pada saat menghadapi persalinan, 1 orang responden $(3,3 \%)$ menyatakan sangat mengganggu karena mengalami gangguan pencernaan pada saat menghadapi persalinan.

Dari jawaban responden terhadap Tingkat Kecemasan Ibu Primipara Dalam Menghadapi Persalinan Di Klinik N. Tambunan Medan dapat diklasifikasikan menjadi 3 kategori, yaitu Kecemasan sedang, Kecemasan Ringan, Kecemasan Berat.

Tabel 3.Distribusi Frekuensi Kecemasan Ibu Primipara dalam Menghadapi Persalinan Di Klinik N.

Tambunan Medan Tahun 2020

\begin{tabular}{ccc}
\hline Kategori & $\mathbf{n}$ & $\mathbf{\%}$ \\
\hline Kecemasan Ringan & 27 & 90 \\
Kecemasan Sedang & 3 & 10 \\
Kecemasan Berat & - & - \\
Jumlah & $\mathbf{3 0}$ & $\mathbf{1 0 0}$ \\
\hline
\end{tabular}

Dari tabel 5.3 menunjukkan bahwa dari 30 orang responden terdapat 27 orang pasien $(90 \%)$ mengalami Kecemasan Ringan, 3 orang pasien (10\%) mengalami Kecemasan Sedang, dan tidak ada pasien (0\%) tidak ada yang mengalami Kecemasan Berat dalam menghadapi persalinan.

\section{PEMBAHASAN}

Kecemasan adalah keadaan yang menggambarkan suatu pengalaman subyektif mengenai ketegangan mental kesukaran dan tekanan yang menyertai suatu konflik atau fenomena yang sangat tidak menyenangkan serta ada hubungannya dengan berbagai perasaan. Kondisi ini dialami oleh seseorang sebagai akibat dari adanya dugaan terhadap bahaya atau frustasi yang mengancam, membahayakan rasa aman, keseimbangan atau kehidupan seorang individu atau kelompok sosialnya. Freund menyatakan bahwa pengalaman tidak menyenangkan ditekan dari alam kesadaran ke alam tidak sadar (unconscious) untuk menghindar realitas. Ibu yang mengandung calon anak pertama biasanya akan mengalami beragam perasaan cemas, perasaan cemas ini akan mudah timbul apabila si ibu sendiri telah mengalami, melihat, ataupun mendengar hal-hal yang tidak diinginkan telah menimpa tetangganya, saudaranya, atau temannya. (Hidayat, 2013)

Kecemasan ringan dapat diketahui dari karakteristik responden pada tingkat usia 23-27 tahun yang menunjukkan 13 orang responden $(43,33 \%)$. Penelitian ini tidak sesuai dengan dengan hasil penelitian Walewangko, (2017) yang mengatakan bahwa perasaan takut dan cemas yaitu di bawah usia 20 tahun serta di atas 3140 tahun karena usia ini merupakan usia kategori kehamilan beresiko tinggi dan seorang ibu yang berusia lebih lanjut 
akan menanggung risiko yang semakin tinggi untuk melahirkan bayi cacat lahir dengan sindrom down.

Menurut karakteristik responden sesuai dengan tingkat pendidikannya didapatkan kecemasan ringan pada tingkat pendidikan (SMA) sebanyak 18 responden $(60 \%)$. Penelitian ini sesuai dengan yang dikatakan pada teori dengan pendidikan manusia dianggap akan memperoleh pengetahuan. Semakin tinggi pendidikan seseorang, maka akan semakin berkualitas pengetahuan seseorang. Tingkat pendidikan juga merupakan salah satu faktor yang memepengaruhi persepsi seseorang untuk lebih mudah menerima ide teknologi baru (Notoadmojo, 2005). Pengetahuan ibu yang pendidikannya tinggi atau $\geq$ SLTA akan lebih siap untuk menghadapi persalinan di banding dengan ibu hamil yang pendidikanya rendah atau $\leq$ SLTP.

Berdasarkan data karakteristik responden sesuai dengan tingkat pekerjaan ditemukan tidak bekerja (IRT) yang mengalami kecemasan ringan sebanyak 26 responden $(86,66 \%)$. Penelitian ini sesuai dengan yang dikemukakan oleh Hurlock, (2002) yang mengatakan bahwa kesesuaian antara pekerjaan dalam diri seseorang memberikan kesan dan pengetahuan, ibu yang bekerja aktif lebih stabil di banding ibu yang tidak bekerja, biasanya ibu yang bekerja akrif dapat mengendalikan emosi dan dapat mengatasi kecemasannya dengan berpikiran positif dan selalu melakukan banyak aktivitas, maka dari itu ibu yang lebih aktif bekerja dapat mengatasi kecemasan yang dapat mengganggu psikologis dan fisiologis.

Berdasarkan data karakteristik responden sesuai dengan tingkat lama menikah ditemukan yang mengalami kecemasan ringan 20 orang responden $(66,66 \%)$ dengan usia lama menikah 1 2 tahun. Penelitian ini tidak sesuai dengan teori yang mengatakan usia pernikahan yang lama dapat membuat ibu merasa cemas dalam menghadapi persalinan karena takut tidak bisa menerima keadaan anak yang akan dilahirkan apakah dengan keadaan yang baik atau cacat.

Berdasarkan data karakteristik responden sesuai dengan suku ditemukan suku Jawa yang mengalami kecemasan ringan sebanyak 13 orang responden $(43,33 \%)$ dan suku Batak sebanyak 7 orang responden (23,33\%). Penelitian ini sesuai dengan teori yang mengatakan suku batak sangat menginginkan keturunan dari anak lakilaki, dengan harapan tersebut dapat mempengaruhi kecemasan ibu primipara yang merasa cemas dan takut apabila anak yang dilahirkan tidak sesuai dengan harapan keluarga, pada suku jawa anak memiliki nilai positif berupa adanya jaminan ekonomi dan psikologis di hari tua, dapat membantu orang tua, memperbaiki ikatan perkawinan dan kelangsungaan keturunan, dengan adanya nilai positif tersebut dapat mempengaruhi kecemasan ibu primípara yang merasa takut dan khawatir akan anak yang dilahirkan (Rooije, 2015)

Berdasarkan data karakteristik responden sesuai dengan tingkat penghasilan perbulan Rp. 1.000.0002.000 .000 ,- ditemukan yang mengalami kecemasan ringan sebanyak 18 orang responden $(60 \%)$. Penelitian ini tidak sesuai dengan teori yang mengatakan dengan penghasilan yang rendah dapat membuat ibu cemas dan takut akan keselamatan ibu dan anak apalagi untuk anak pertama sangat diharapkan sekali anak dapat lahir dengan selamat dan dengan perawatan yang baik.

\section{KESIMPULAN}

Penelitian ini menunjukkan bahwa dua orang responden menyatakan tidak sama sekali khawatir akan terjadi 
sesuatu yang buruk pada saat menghadapi persalinan dan 14 orang responden menyatakan tidak sama sekali merasa tegang pada otot-otot leher, dada dan punggung, 15 orang responden menyatakan iya, tapi tidak mengganggu menggoyangkan tungkai kaki pada saat menghadapi persalinan. Pada tanda gejala overaktifitas otonomik 14 orang responden menyatakan tidak sama sekali merasa kehilangan kesadaran pada saat menghadapi persalinan, 15 orang reponden menyatakan iya, tapi tidak mengganggu merasa kehilangan kesadaran pada saat menghadapi persalinan, 1 orang responden menyatakan sangat mengganggu karena mengalami gangguan pencernaan pada saat menghadapi persalinan. Dari 30 orang responden terdapat 27 orang pasien mengalami Kecemasan Ringan, 3 orang pasien mengalami Kecemasan Sedang, dan tidak ada yang mengalami Kecemasan Berat dalam menghadapi Persalinan.

\section{DAFTAR PUSTAKA}

Detiana, Priala, (2010). Hamil Aman Dan Nyaman di Atas 30 Tahun, Yogyakarta.

Hidayat,S.,Sumarni, S. (2013). Kecemasan Ibu Hamil Dalam Menghadapi Proses Persalinan. Jurnal Kesehatan Wiaraja Medika, Vol 2 (1). Retrieved from http://download.garuda.ristekdikti .go.id/article.php?article $=1078221$ \&val $=6831 \&$ title $=$ KECEMASAN $\% 20$ IBU\%20HAMIL\%20DALAM\%20ME NGHADAPI\%20PROSES\%20PERSA LINAN

Maryuni, Anik. (2013), Nyeri Dalam Persalinan Teknik dan Cara Penanganannya, Jakarta

Notoatmodjo, S. (2005). Metodologi Penelitian Kesehatan, Cetakan III, Edisi Revisi, Jakarta.

Nursalam. (2008). Konsep dan Penerapan Metodologi Penelitian IImu Keperawatan: Pedoman Skripsi, Tesis dan Instrumen
Penelitian Keperawatan (edisi kedua), Jakarta

Risky Anggraini. (2010). Proposal penelitian Karakteristik Ibu Hamil Yang Mengalami Kecemasan Dalam Menghadapi Persalinandi Bps Uswatun Poncowati Lampung Tengah, Di peroleh tanggal 8 Maret 2012 dari http://dc378.4shared.com/doc/djr AqZbV/preview.html

Roojie, R., \& Tandipajung, T., Bukasiang, M., (2015). FaktorFaktor yang berhubungan dengan respon cemas pada ibu hamil di poliklinik kebidanan rsal bitung. Ejurnal Sariputra, Vol2. (3). Retrieved from http://jurnal.unsrittomohon.ac.id/i ndex.php?journal $=$ ejurnal\&page $=a$ rticle\&op =download\&path\%5B\%5 $D=112$ \&path\%5B\%5D =102

Universitas Sumatera Utara. (2013). Kecemasan Ibu bersalin Primigravida Kala 1, di akses tanggal 2 Maret 2012 darihttp://repository.usu.ac.id/bits tream/123456789/20180/5/Chapt er\%20I.pdf

Walewangko, A. (2017). Faktor-faktor Yang Mempengaruhi Tingkat Kecemasan Ibu Hamil Dalam Menghadapi Proses Persalinan Di ruangan Maria RSU Bethesda GMIM Tomohon, Diperoleh tanggal 23 Mei 2020

dari http://jurnal.unsrittomohon.ac.id/i ndex.php?journal =ejurnal\&page $=a$ rticle\&op=download\&path\%5B\%5 $\mathrm{D}=$ 293\&path\%5B\%5D =265 